proposed solutions ranged from creation of a new information system on science and technology for development, to provision of information materials to the developing countries at a moderate cost, and promotion of public understanding of science and technology through mass media. International information agencies, scientific unions and private publishers can play substantial roles in these schemes. It was argued, for example, that sale of books and journals to the developing countries is only a minor fraction of the total sale, and the publishers should consider reducing the prices to a level which these countries can afford. Schemes for book donation such as operated by UNESCO should also be made more effective.

Nowhere is the need for public understanding of science and technology more acutely felt in the developing world than in the fields of health and agriculture. Many tropical diseases are largely preventable: hookworms are prevented by wearing shoes, cholera by having clean water supply, xerophthalmia by eating food containing vitamin $\mathrm{A}$, etc. The yields of major food crops can be increased several fold through proper fertilizer supplies, pest management and irrigation. Apart from the fact that money and supplies are simply not available, the necessary information is also not accessible to the majority of the rural population. Technology transfer for village industries also present similar problems. The development of extension services and non-formal education deserve high priority.

The strengthening of the scientific and technological capacity of the developing world will be both expensive and timeconsuming. Some delegates even expressed despair that this goal will ever be significantly achieved in the majority of developing countries. An alternative goal was proposed whereby a group of countries within the same region would share their resources and pool external aid in a limited number of large and effective institutions. While this arrangement could possibly be of benefit for certain projects which need a considerable amount of scientific infrastructure, its main drawback is the continuing dependence of the smaller and less developed countries, their big brothers merely being in the same region rather than somewhere to the North. Whatever the strategy, it was clear that much more co-operation from the developed countries should be forthcoming. This will have to include provision of scientific equipment and maintenance facilities, information, help in scientific and technical education, exchange of scientists and technologists. The developing countries themselves will have to try harder to support their scientific and technological activities, including education.

Developing countries often have an asset in abundance of natural resources, solar energy supplies and a climate suited for rapid bioconversions. The meeting agreed that these local advantages should be utilized, which implies that the problems for science and technology will often be very different from those in developed countries. It was proposed that a consortium of experts from the developing countries be formed to deal with training and development of technology for optimum utilization natural resources. It is hoped that international agencies including COSTED will take up this matter further.

\title{
Hunting Mongolian dinosaurs
}

COMECON, in the thirty years of its existence, has provided the framework for numerous scientific cooperation projects. One of the most interesting and most unusual was the Polish-Mongolian series of palaeontological expeditions of 19631971, organised by Dr. Zofia KielanJaworowska of the Polish Academy's Institute of Palaeozoology. (For the latest results, see $\mathrm{p}$ 792.)

These expeditions not only produced a wealth of scientific material on dinosaurs, dinosaur eggs and mezozoic mammals, which is gradually being published in Palaeontologia Polonica (the final report is expected to extend to some 16-20 thick volumes; No. 8 is now about to appear); they also resulted in an excellent "popular" book on palaeontology - Dr. Kielan-Jaworowska's Hunting for Dinosaurs. Most important, perhaps, as I learned when I spoke with Dr. KielanJaworowska in Warsaw, they provide a fascinating commentary on how formal "scientific cooperation" can work.

Not that the Gobi expeditions were entirely typical! Cooperation agreements within Comecon tend to take place between the Soviet Union and one or more of the smaller member-countries - a major project without Soviet participation is somewhat rare. In fact, Dr. KielanJaworowska explained, at the beginning there was some talk of Soviet participation, but the Soviet Palaeontological Institute was "too busy."

The idea for such an expedition arose in 1961, when the representatives of the Comecon Academies of Science met in
Warsaw. During this meeting, a cooperation was signed between the Polish and Mongolian Academies, and Dr. KielanJaworowska put forward a proposal for joint palaeontological expeditions. "This was my private dream,' she explained, "and also the dream of many workers in this institute. Mongolia is an unusual country, especially for vertebrate palaeontology. The odd thing is that we were invertebrate palaeontologists at the time!"

In due course, Dr. Kielan-Jaworowska was appointed to lead the expeditions. One of the main practical problems was, of course, that Poland is among the most scientifically advanced Comecon countries, while Mongolia is relatively backward. For the project to be genuinely bilateral, some preliminary training was necessary. "We had to help the Mongolian Academy,' she said. "We had to teach their scientists. They came during their training to our institute and we published some joint papers. At that time there were about ten Mongolian palaeontologists working in Ulan-Bator. Two of these Demberelyin Dashzeveg (a specialist on mammals) and Rinchen Barsbold (dinosaurs) - were very gifted.'

The field-work of the expeditions proved successful beyond all hopes. Major finds included dinosaur eggs, fossil tortoises, many new genera of dinosaurs, and, for the first time, well-preserved skulls of multituberculates, which threw new light on the mesozoic "dark ages" of mammalian history. Subsequent study of the multituberculate finds showed that these nonplacental mammals were closely related to

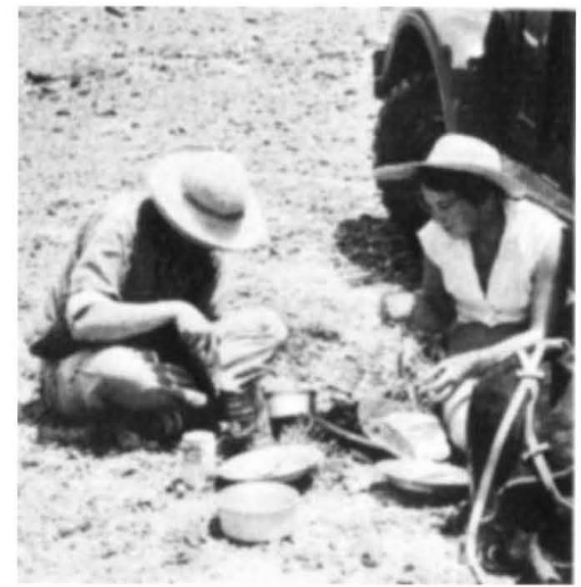

On the trail: Dr Kielan-Jaworowska (right) and colleague

the monotremes as far as brain structure was concerned, thereby raising the further question of whether they were viviparous or oviparous.

Poland has an excellent network of museums, Mongolia has simply the municipal museum in Ulan Bator. One might be tempted, therefore, to imagine that the bulk of the material will remain in Poland. 'Not at all,' said Dr. KielanJaworowsaka. "The agreement is that after we have studied the material, part of it will be sent back to Ulan Bator ",

"There will be a true pay-off for both sides,' she added. "We have got some most interesting material, which throws great light on some of the most important questions of evolution. And the Mongolians will get good material and the basis for a good museum.

Vera Rich 